\title{
Carcass quality of crossbred steers with different degrees of zebu blood in the genotype: meta-analysis
}

\author{
Tiago Venturini ${ }^{1}$, Luís Fernando Glasenapp de Menezes ${ }^{1}$, Fernando Kuss ${ }^{1}$, Thomas Newton \\ Martin $^{1}$, Douglas Vonz ${ }^{1}$, Wagner Paris ${ }^{1}$
}

1 Universidade Tecnológica Federal do Paraná - Campus Dois Vizinhos.

\begin{abstract}
In order to evaluate the effect of the different percentages of zebu blood in the genotype of crossbred steers on carcass traits, a meta-analysis was carried out, using 30 studies conducted in Brazil that have been published since the year 2000. The parameters evaluated were hot carcass weight (221 estimates), cold carcass weight (232), hot carcass (236) and cold carcass yield (223), subcutaneous fat thickness (238) and the percentages of saw cut (233), forequarter (234) and sidecut (246 estimates). Initially, exploratory analysis was performed for each of the variables for detection of publication vices through the dispersion of observations by pointing out the outliers eliminated. Normality tests were normal and the data were subjected to analysis of variance for the regression study, which were assessed to the third degree. Weights of hot carcass and cold carcass, hot and cold carcass yield and the percentage of saw cut had a quadratic effect on animals with the presence of zebu blood, indicating superiority of crossbred animals. The regression equation showed that $66 ; 50 ; 72 ; 81$ and $59 \%$ of zebu in crossbred animals showed higher hot and cold carcass weight, hot and cold carcass percentage and saw cut, respectively. Fat thickness was not influenced by the degree of zebu in the genotype. The percentage of forequarter has a positive response by increasing the degree of zebu in the genotype, while the sidecut has a negative answer. The crossbreeding between zebu and European breeds provides carcasses with better quality than purebred animals.
\end{abstract}

Key Words: carcass yield, crossbreeding, heterosis

\section{Introduction}

With the increase in the production and the amount of beef produced and exported, the production chain of this segment in Brazil has stood out internationally. A major concern in the country for the consumer market is the compliance with the requirements and needs in relation to the quantity and quality of the final product; in other words, the carcass and meat produced (Pacheco et al., 2005), keeping the basic conditions required, which are hygienic and sanitary safeness, nutritional value, produce traceability and sensory characteristics (Pineda \& Rocha, 2002).

The crossbreeding between European and Zebu breeds is one of the practices used to increase animal performance, widely used in countries with emphasis on beef production, like the United States of America, New Zealand, Canada and Australia, reaching levels above $80 \%$ of application on herds (Sundstrom et al., 1994).

The use of European breeds (Bos taurus taurus) in crossbreeding helps to improve the quality of carcass and meat, besides reducing the age at slaughter. Since the genotype zebu (Bos taurus indicus) collaborates with its rusticity and adaptation to tropical climates, due to its greater resistance to pests and tolerance to heat, allied to these factors, the crossbreeding provides greater heterosis (Menezes et al., 2005).

In the study of carcass production quality, several factors of commercial interest such as improving the yield of the carcass and commercial cuts, the weight of the cut and the degree of final touch are taken into account by the slaughterhouses (Costa et al. 2002; Arboitte et al., 2004).

The literature has several studies related to carcass quality and beef and they often report conflicting results. Thus, this study aims to evaluate the variations found in experimental research and conduct a scientific systematization of information to obtain more precise information to support producers in the definition of which degree of participation of zebu in the genotype provides greater income to the producers, as well as to assess the possibility of the beef industry's being more profitable and pay a fairer price for the product.

One way to standardize the results and observe trends is a meta-analysis, which combines the results of several experiments related to the same subject in order to cover a group of evidences (Hauptli et al., 2007). In this study, the influence of the degree of zebu in genotype on the characteristics that affect carcass quality of beef cattle was evaluated. 


\section{Material and Methods}

The study was conducted at the Universidade Tecnológica Federal do Paraná - Campus Dois Vizinhos (UTFPR-DV). Twenty-two articles published on the Revista Brasileira de Zootecnia (Leme et al., 2000, Prado et al. 2000; Feijó et al. 2001; Restle et al. 2001; Zervoudakis et al., 2001; Costa et al. , 2002; Faturi et al., 2002; Santos et al., 2002; Vaz et al., 2002; Vaz \& Restle, 2003; Arboitte et al., 2004; Menezes et al., 2005, Pacheco et al., 2005 ; Vaz \& Restle, 2005; Canesin et al., 2006; Bonilha et al., 2007; Coan et al., 2008; Freitas et al., 2008; Igarasi et al., 2008; Marcondes et al., 2008; Ribeiro et al., 2008; Silva et al., 2008; Metz et al., 2009) six dissertations (Aferri, 2003; Kuss, 2004; Menezes, 2004; Pacheco, 2004; Sachet, 2009; Santos, 2005) and two theses (Pereira, 2006; Menezes, 2008) in Animal Science at Universidade Federal de Santa Maria (UFSM) and Universidade de São Paulo (USP) from 2000 to 2009 were used (Table 1) .

From the articles published in the journals, the average data were extracted, and in dissertations, individual results were published in the appendices. The survey included characteristics that affect carcass quality, and was performed using as keywords: carcass, cattle, calves and degree of blood. One-hundred and eight articles related to the characteristics sought were found and, after accurate analysis, 30 articles were selected for meta-analysis having as criteria the use of bulls aged 24 months, purebred or crossbred.

The main variables analyzed were: hot carcass weight (221 estimates extracted), cold carcass weight (232), hot carcass yield (236) and cold carcass (223), fat thickness (238), percentage of saw cut (233), percentage for forequarter (234) and percentage of sidecut (246 animals evaluated).

The values mentioned in the selected studies were related to the interference of the percentage of zebu blood of animals evaluated. The animals used in experiments were divided into nine categories according to their genotypes: $0,25,31.25,37.5,50,58.75,62.5,75$ and $100 \%$ of zebu blood in the genotype. The database was developed in a Microsoft Excel ${ }^{\circledR}$ spreadsheet from the values discussed in the publications. The meta-analysis of the variables followed the following steps: exploratory analysis of the data set, which aims to detect the presence of addiction to publication,

Table 1 - List of studies addressed to perform the meta-analysis

\begin{tabular}{|c|c|c|c|c|c|}
\hline \multirow[t]{2}{*}{ Author } & \multicolumn{2}{|c|}{ Breed } & \multirow[t]{2}{*}{ Author } & \multicolumn{2}{|c|}{ Breed } \\
\hline & Zebu (\%) & European (\%) & & Zebu (\%) & European (\%) \\
\hline Pacheco et al. (2005) & Nellore $(37.5,62.5)$ & Charolais $(62.5,37.5)$ & Menezes (2004) & $*$ & Charolais (100) \\
\hline Pacheco (2004) & Nellore (62.5; 37.5) & Charolais (37.5; 62.5) & & $\begin{array}{c}\text { Nellore }(25 ; 32.5 ; \\
\text { 37.5; 62.5; 68.5; 75) }\end{array}$ & $\begin{array}{c}\text { Charolais (25; 32.5; } \\
37.5 ; 62.5 ; 68.5 ; 75)\end{array}$ \\
\hline Freitas et al. (2008) & Nellore (100) & * & & Nellore (100) & $*$ \\
\hline \multirow[t]{10}{*}{ Leme et al. (2000) } & Nellore (100) & $*$ & Kuss (2004) & $\begin{array}{l}\text { Nellore }(25 ; 32.5 ; \\
62.5 ; 75)\end{array}$ & $\begin{array}{l}\text { Charolais (25; 32.5; } \\
\text { 62.5; 75) }\end{array}$ \\
\hline & Nellore (50) & South Devon (50) & Ribeiro et al. (2008) & Nellore (100) & $*$ \\
\hline & Nellore (50) & Hereford (50) & & Guzerá/Nellore (100) & $*$ \\
\hline & Nellore (50) & Aberdeen angus (50) & & Brahman/Nellore (100) & $*$ \\
\hline & Nellore (50) & Red angus (50) & Bonilha et al. (2007) & Nellore (100) & $*$ \\
\hline & Nellore (50) & Caracu (50) & & Guzerá (100) & $*$ \\
\hline & Nellore (50) & Limousin (50) & & Gir (100) & $*$ \\
\hline & Nellore (50) & Simental (50) & & $*$ & Caracu(100) \\
\hline & Nellore (50) & Charolais (50) & Silva et al. (2008) & Nellore (100) & $*$ \\
\hline & $*$ & Holandês (100) & Metz et al. (2009) & Nellore (62.5) & Charolais (37.5) \\
\hline Prado et al. (2000) & Nellore (50) & Angus (50) & Sachet (2009) & Nellore (50) & Charolais (50) \\
\hline Zervoudakis et al. (2001) & Nellore (50) & Holandês (50) & Aferri (2003) & Nellore (25) & Simental/Brangus (75) \\
\hline Feijó et al. (2001) & Nellore (50) & Aberdeen angus (50) & Pereira (2006) & Nellore (50) & Aberdeen angus (50) \\
\hline Santos et al. (2002) & Nellore (50) & Limousin (50) & & Brahman/Nellore (100) & $*$ \\
\hline Santos (2005) & $\begin{array}{c}\text { Nellore }(25 ; 37.5 ; \\
62.5 ; 75)\end{array}$ & $\begin{array}{c}\text { Charolais (25; 37.5; } \\
62.5 ; 75)\end{array}$ & & Nellore (100) & $*$ \\
\hline \multirow[t]{3}{*}{ Vaz et al. (2002) } & Nellore (37.5) & Hereford (62.5) & Coan et al. (2008) & Nellore (100) & $*$ \\
\hline & $*$ & Jersey/Hereford (100) & Restle et al. (2002) & Nellore (50) & Charolais (50) \\
\hline & $*$ & Hereford (100) & & $*$ & Charolais (100) \\
\hline Vaz et al. (2005) & $*$ & Hereford (100) & Restle et al. (2001) & $*$ & Charolais (100) \\
\hline Vaz et al. (2002) & $*$ & Hereford (100) & & Nellore (100) & $*$ \\
\hline Vaz et al. (2003) & $*$ & Charolais (100) & & Nellore $(25 ; 50 ; 75)$ & Charolais $(25 ; 50 ; 75)$ \\
\hline Arboitte et al. (2004) & Nellore (62.5) & Charolais (37.5) & Costa et al. (2002) & $*$ & Red angus (100) \\
\hline Canesin et al. (2006) & Nellore (50) & Charolais (50) & Faturi et al. (2002) & $*$ & Charolais (100) \\
\hline Igarasi et al. (2008) & Nellore (50) & Red angus (50) & & Nellore (100) & $*$ \\
\hline Menezes et al. (2005) & Nellore (50) & Charolais (50) & & Nellore & Charolais \\
\hline Menezes (2008) & $*$ & Devon (100) & Marcondes et al. (2008) & Nellore (100) & $*$ \\
\hline
\end{tabular}


in other words, the presence of disparate data (outliers) for a certain trait in the studies. Outliers were determined with the help of TC2D software, which pointed the data with values of twice the standard deviation, allowing the elimination of values over this limit . The tests of normality applied to the variables were: Kolmogorov-Smirnov, Cramer-von Mises, Anderson-Darling, Kuiper, Watson, Lilliefors and ShapiroWilk test, using the software Assistat (Silva \& Azevedo, 2002). The data were subjected to analysis of variance and the estimation of regression equations to the third grade was achieved through the statistical software SAS (2001).

\section{Results and Discussion}

Only purebred animals did not reach the average cold carcass weight of $230 \mathrm{~kg}$ (Table 2), minimum sought by the beef industry to reduce the costs of production (Costa et al., 2002). In all degrees of blood, there were animals that showed carcasses with weights inferior to $230 \mathrm{~kg}$. Carcasses with less weight (over $180 \mathrm{~kg}$ ) are being gradually accepted by butchers and supermarkets, because the animals are associated with lower age and better meat quality (Costa et al., 2002).

In spite of the use of meta-analysis, which could lead to high variability of the data, the coefficient of variation $(\mathrm{CV}=11.5 \%)$ for hot carcass weight was similar to that found in the literature: Zervoudakis et al. (2001), 8.9\%; Canesin et al. (2006), 7.74\%; Marcondes et al. (2008), 11.63\%. On the other hand, the coefficient of variation for the cold carcass weight (14.1\%) was higher than that observed in the literature: Kuss et al. (2005), 8.83\%; Canesin et al. (2006), 7.96\%; Silva et al. (2008), 6.63\%. The cold carcass weight is influenced by other factors that are not inherent by the

Table 2 - Statistics of position and dispersion for hot and cold carcass weight and fat thickness according to the degree of blood in the genotype of zebu bulls

\begin{tabular}{|c|c|c|c|c|c|c|c|c|c|c|}
\hline \multirow[b]{2}{*}{ Descriptive statistics } & \multicolumn{10}{|c|}{ \% zebu blood } \\
\hline & 0 & 25 & 31.25 & 37.5 & 50 & 58.75 & 62.5 & 75 & 100 & Genera \\
\hline & \multicolumn{10}{|c|}{ Weight of hot carcass, kg } \\
\hline Minimum & 169.2 & 214.0 & 213.0 & 200.8 & 203.9 & 212.9 & 206.0 & 209.5 & 198.0 & 169.2 \\
\hline Maximum & 242.6 & 273.2 & 244.5 & 287.6 & 292.0 & 224.3 & 299.0 & 270.2 & 276.2 & 299.0 \\
\hline Arithmetic mean & 204.2 & 245.3 & 234.1 & 247.2 & 251.5 & 218.6 & 252.2 & 243.4 & 246.2 & 240.6 \\
\hline LCI* & 198.3 & 225.3 & 211.1 & 238.7 & 246.1 & 210.9 & 244.5 & 229.1 & 237.1 & 237.0 \\
\hline Standard deviation & 18.4 & 24.0 & 14.5 & 24.3 & 21.6 & 4.8 & 23.4 & 21.2 & 24.0 & 27.7 \\
\hline Variance & 339.7 & 575.4 & 209.7 & 590.7 & 464.8 & 23.3 & 545.6 & 450.9 & 573.7 & 768.2 \\
\hline $\mathrm{CV}^{*}$ & 9.0 & 9.8 & 6.2 & 9.8 & 8.6 & 2.2 & 9.3 & 8.7 & 9.7 & 11.5 \\
\hline \multirow[t]{2}{*}{$\mathrm{DN}^{* *}$} & $\mathrm{TN}$ & $\mathrm{TN}$ & $\mathrm{TN}$ & TN & TN & $\mathrm{TN}$ & $\mathrm{TN}$ & $\mathrm{TN}$ & $1,4,6$ & 1,6 \\
\hline & \multicolumn{10}{|c|}{ Weight of cold carcass, kg } \\
\hline $\mathrm{LCI}^{*}$ & 201.2 & 237.64 & 224.2 & 232.5 & 232.6 & 199.9 & 235.9 & 215.9 & 188.4 & 224.9 \\
\hline $\mathrm{UCL}^{*}$ & 213.7 & 274.22 & 285,9 & 249.4 & 247.7 & 267.5 & 251.8 & 247.8 & 216.9 & 233.2 \\
\hline Mean deviation & 17.7 & 25.89 & 29.2 & 19.1 & 18.9 & 27.5 & 19.4 & 23.1 & 30.4 & 26.5 \\
\hline Standard deviation & 22.6 & 30.25 & 33.3 & 24.0 & 24.6 & 32.2 & 24.3 & 27.6 & 37.4 & 32.2 \\
\hline Variance & 512.4 & 915.25 & 1110.6 & 576.2 & 606.9 & 1035.8 & 590.9 & 764.2 & 1401.3 & 1039.6 \\
\hline $\mathrm{CV}^{*}$ & 10.9 & 11.82 & 13.1 & 9.9 & 10.3 & 13.8 & 10.0 & 11.9 & 18.5 & 14.1 \\
\hline \multirow[t]{2}{*}{$\mathrm{DN}^{* *}$} & $\mathrm{TN}$ & $1,2,3,5,6,7$ & $1,2,3,5,6,7$ & $\mathrm{TN}$ & $\mathrm{TN}$ & 3 & $\mathrm{TN}$ & $2,3,4,5,6,7$ & $\mathrm{TN}$ & $\mathrm{TN}$ \\
\hline & \multicolumn{10}{|c|}{ Fat thickness, mm } \\
\hline $\mathrm{N}^{*}$ & 52 & 10 & 7 & 28 & 44 & 5 & 37 & 16 & 39 & 238 \\
\hline Minimum & 1.3 & 3.0 & 3.0 & 2.5 & 2.0 & 3.5 & 2.4 & 2.5 & 1.9 & 1.3 \\
\hline Maximum & 6.3 & 6.6 & 6.0 & 7.5 & 7.9 & 6.5 & 7.3 & 7.0 & 7.4 & 7.9 \\
\hline Arithmetic mean & 4.0 & 4.2 & 4.9 & 4.5 & 4.4 & 4.9 & 4.8 & 5.0 & 4.5 & 4.5 \\
\hline
\end{tabular}

* $\mathrm{N}$ = number of observation; LCI = lower confidence limits; UCL = upper confidence limits; $\mathrm{CV}=$ coefficient of variation; DN = adherence data.

** The values follow a normal distribution for the Kolmogorov-Smirnov (1), Cramer-von Mises (2), Anderson-Darling (3), Kuiper (4), Watson (5), Lilliefors (6), ShapiroWilk (7), show normal distribution for all tests (TN) and do not present normal distribution for any test (NN). 
animal; for instance, the temperature in the cold may increase or decrease the carcass yield during the cooling, which could not be measured in the meta-analysis.

The loss by chilling reflects the decrease of the carcass weight during the cooling process in the first 24 hours after slaughter (Menezes et al., 2005). Moreover, studies show that chilling loss is influenced by the thickness of subcutaneous fat (Muller, 1987; Arboitte et al., 2004). According to Muller (1987), lower rates of breakdown are observed in carcasses with higher degree of subcutaneous fat, since it acts as an insulator, preventing losses from dehydration. The subcutaneous fat thickness (FT) presented high variability (32.80\% average CV), which may have contributed to the increase in the coefficient of variation of the cold carcass weight. The high variability for this characteristic is reported in the literature: Canesin et al. (2006), 44.84\%; Silva et al. (2008), 52.92\%; Igarasi et al. (2008), 22.98\%. Lopes et al. (2008) conducted a meta-analysis for carcass traits of cattle from different genetic groups and found that the contribution of the degree of zebu blood on the thickness of fat was only positive when the crossbreeding was carried out with European continental origin ones, while when done between zebu and British, the presence of zebu genotype decreased the degree of finishing on the carcass. As in this analysis there was no such distinction between the origins of European breeds involved in the crossbreeds, the data variation for fat thickness was high.

The fat thickness was not influenced by the presence of zebu blood in the genotype of animals. The high variability $(\mathrm{CV}=32.80 \%)$ data contributed to that outcome. Furthermore, the thickness of fat is one of the main criteria at the moment of slaughter, since, along with the carcass weight, is one of the requirements of beef industry. Slaughterhouses require 3 to $6 \mathrm{~mm}$ of fat thickness (Costa et al., 2002). In the studies evaluated, fat thickness ranged from 1.33 to $7.90 \mathrm{~mm}$. The high variation in all genotypes and degree of finish was more influenced by the procedures of researchers than by the genotype involved.

The weights of hot and cold carcass were influenced in a quadratic pattern (Figure 1) by the degree of Zebu blood $(\mathrm{HCW}=205.36+1.429 *-0.0108 *$ zebu2 zebu, PCF $=213.58$ $+1.384 *$ zebu - zebu2 $0.014 *$ ), since the highest values were obtained from crossbred animals (66 and 50\% of zebu blood, respectively).

The hot carcass weight of the animals showed differences of up to $47 \mathrm{~kg}$ between pure European and crossbred animals (66\% of zebu blood) and this difference may have been favored by the increase in carcass weight caused by heterosis provided at the junction between European and zebu breeds (Menezes et al., 2005). Koger et al. (1975)
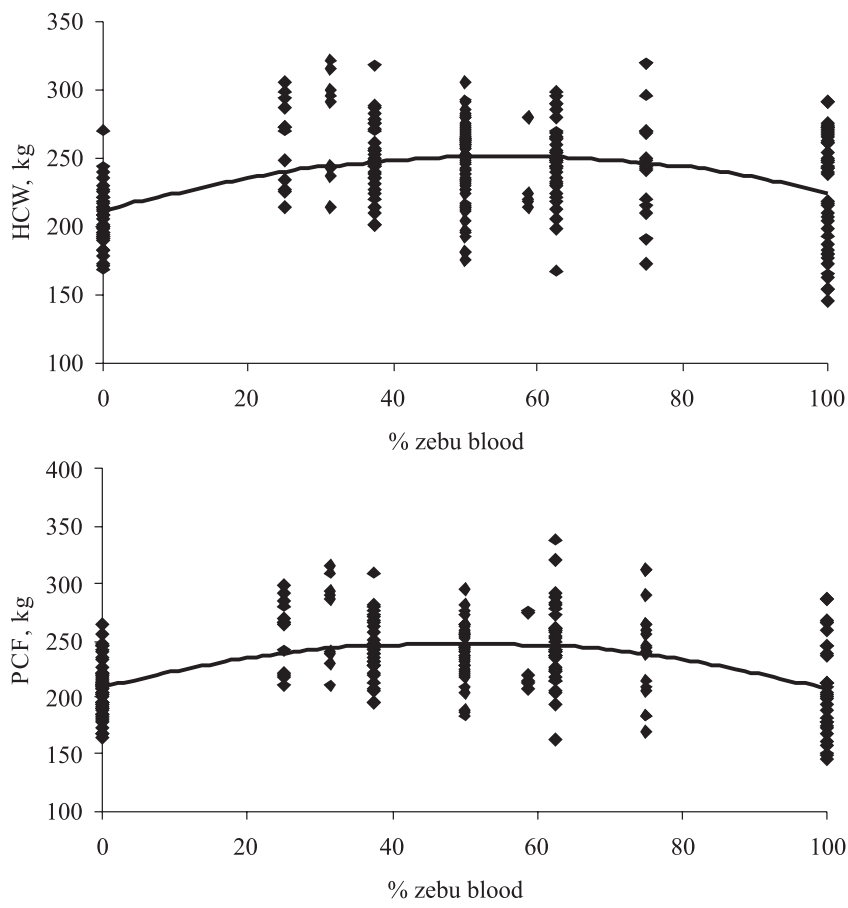

Figure 1 - Relationship between percentage of zebu blood and hot carcass weight (HCW) and cold carcass (PCF) of steers slaughtered at 24 months of age on average.

were the first to demonstrate linearity between heterosis and heterozygosis. In this analysis, maximum results for cold carcass weight were found when the animals had $50 \%$ of zebu blood. Animals of $1 / 2$ blood showed $100 \%$ heterozygosis and are expected to have maximum heterosis. In this analysis, the maximum results for cold carcass weight were observed when the animals had $50 \%$ of zebu blood. Restle et al. (1999), working with different degrees of blood Hereford $\times$ Nellore, and Menezes et al. (2005), with crossbreeding between Charolais and Nellore, verified that the maximum carcass weight occurs with 41 and $42 \%$ of European blood in the genotype, respectively.

As it happened with the weights of carcass, the data variation of hot carcass yield $(\mathrm{CV}=3.7 \%)$ and cold $(\mathrm{CV}=$ $4.3 \%$, Table 3) was close to that found in the literature (Canesin et al., 2006, CV = 11.43 and 4.53\%, Silva et al., 2008: 2.82 and $2.84 \%$ for hot and cold carcass yield, respectively).

The lowest values for the hot and cold carcass yield were observed in 100\% European animals, both for the minimum (49.56 and 48.10\%) and maximum values (55.87 and $55.20 \%$ ). The superiority in carcass yield of zebu blood in animals with genotype can be attributed to the relative weight of lower legs, head, skin (Menezes et al., 2009) and especially of the gastrointestinal tract (Menezes et al., 2007), in addition to thinner skin and more surface area on the body, which are characteristics of zebu genotypes adapted to warmer climates. 
Table 3 - Statistics of position and dispersion of hot and cold carcass yield according to the degree of blood in the genotype of zebu bulls

\begin{tabular}{|c|c|c|c|c|c|c|c|c|c|c|}
\hline \multirow[b]{2}{*}{ Descriptive statistics } & \multicolumn{10}{|c|}{$\%$ zebu blood } \\
\hline & 0 & 25 & 31.25 & 37.5 & 50 & 58.75 & 62.5 & 75 & 100 & General \\
\hline & \multicolumn{10}{|c|}{ Hot carcass yield, \% } \\
\hline $\mathrm{N}^{*}$ & 35 & 9 & 8 & 32 & 52 & 6 & 40 & 16 & 38 & 236 \\
\hline Minimum & 49.6 & 53.1 & 53.9 & 52.8 & 52.1 & 55.9 & 52.0 & 54.8 & 52.0 & 49.6 \\
\hline Maxim & 55.9 & 58.6 & 58.2 & 59.5 & 60.0 & 59.5 & 60.0 & 60.0 & 58.8 & 60.0 \\
\hline Arithmetic mean & 53.5 & 56.8 & 56.4 & 55.9 & 55.1 & 57.5 & 56.0 & 56.5 & 56.1 & 10.4 \\
\hline $\mathrm{LCI}^{*}$ & 52.9 & 55.6 & 55.3 & 55.3 & 54.6 & 56.1 & 55.4 & 55.6 & 55.5 & 55.3 \\
\hline UCL* & 54.1 & 58.0 & 57.6 & 56.5 & 55.7 & 59.0 & 56.6 & 57.4 & 56.7 & 55.8 \\
\hline Mean deviation & 1.5 & 1.0 & 1.0 & 1.6 & 1.7 & 1.0 & 1.6 & 1.3 & 1.5 & 1.7 \\
\hline Standard deviation & 1.8 & 1.5 & 1.3 & 1.8 & 2.0 & 1.4 & 2.0 & 1.6 & 1.8 & 2.1 \\
\hline Variance & 3.3 & 2.4 & 1.8 & 3.4 & 4.1 & 1.9 & 3.9 & 2.7 & 3.2 & 4.3 \\
\hline $\mathrm{CV}^{*}$ & 3.4 & 2.7 & 2.4 & 3.3 & 3.7 & 2.4 & 3.5 & 2.9 & 3.2 & 3.7 \\
\hline \multirow[t]{2}{*}{$\mathrm{DN}^{* *}$} & $1,2,4,5,6$ & 4.6 & $\mathrm{TN}$ & $2,3,7$ & $\mathrm{TN}$ & $\mathrm{TN}$ & $\mathrm{TN}$ & NN & $1,3,4,6,7$ & $2,3,5,6,7$ \\
\hline & \multicolumn{10}{|c|}{ Cold carcass yield, \% } \\
\hline$N^{*}$ & 51 & 10 & 8 & 32 & 28 & 6 & 40 & 17 & 31 & 223 \\
\hline Minimum & 48.1 & 51.4 & 52.8 & 51.2 & 50.7 & 54.3 & 50.8 & 51.8 & 51.0 & 48.1 \\
\hline Maximum & 55.2 & 57.1 & 57.2 & 58.3 & 58.5 & 57.9 & 59.0 & 58.6 & 59.0 & 59.0 \\
\hline Arithmetic mean & 51.9 & 54.8 & 55.3 & 54.5 & 54.1 & 56.2 & 54.6 & 55.1 & 55.0 & 54.1 \\
\hline LCI* & 51.3 & 53.3 & 54.1 & 53.8 & 53.2 & 54.7 & 54.0 & 54.2 & 54.1 & 53.8 \\
\hline UCL* & 52.4 & 56.3 & 56.5 & 55.2 & 55.0 & 57.8 & 55.1 & 56.0 & 55.8 & 54.4 \\
\hline Mean deviation & 1.5 & 1.7 & 1.1 & 1.7 & 2.1 & 1.1 & 1.5 & 1.4 & 2.0 & 1.9 \\
\hline Standard deviation & 1.9 & 2.1 & 14 & 1.9 & 2.4 & 1.5 & 1.9 & 1.8 & 2.4 & 2.3 \\
\hline Variance & 3.5 & 4.4 & 2.0 & 3.7 & 5.6 & 2.2 & 3.5 & 3.3 & 5.6 & 5.5 \\
\hline$\underline{C V * \mathrm{DN}^{* *}}$ & $3.61,2,5,6$ & $3.83,4,6,7$ & $2.6 \mathrm{TN}$ & 3.53 .7 & $4.4 \mathrm{NN}$ & $2.6 \mathrm{TN}$ & $3.4 \mathrm{TN}$ & $3.3 \mathrm{TN}$ & $4.3 \mathrm{TN}$ & $4.32,3,4,5,6$ \\
\hline
\end{tabular}

* $\mathrm{N}=$ number of observation; $\mathrm{LCI}=$ lower confidence limits; UCL = upper confidence limits, $\mathrm{CV}=$ coefficient of variation, DN = adherence data.

** The figures follow a normal distribution for the Kolmogorov-Smirnov (1), Cramer-von Mises (2), Anderson-Darling (3), Kuiper (4), Watson (5), Lilliefors (6), ShapiroWilk (7), show normal distribution for all tests (TN) and do not present normal distribution for any tests (NN).

Regression analysis (Figure 2) indicated a quadratic effect of the presence of blood in the zebu genotype in relation to carcass yield. Several studies indicate linearity of carcass yield in the presence of zebu blood in genotype (Restle et al., 1999, 2000). On the other hand, Menezes et al. (2005) observed positive heterosis for hot (3.22\%) and cold (3.45\%) carcass yield, indicating that the crossbreds were higher than purebreds. In that study, the authors remarked that all crossbred genotypes (Charolais - $\mathrm{C}$ and Nellore - $\mathrm{N}$ ) studied (3/4ch 1/4N, 3/4N 1/4C, 5/8C 3/8N, 5/8N 3/8C; $11 / 16 \mathrm{C} 5 / 16 \mathrm{C} 5 / 16 \mathrm{~N}$ and $11 / 16 \mathrm{~N}$ ) had higher carcass yield than Nellore purebreds.

Arboitte et al. (2004) and Kuss et al. (2005) report that several researchers found an increasing yield according to weight at slaughter. In this study there was no relationship between income and housing of animals slaughtered $(r=-0.03, P=0.64)$. However, carcass yield was positively correlated with carcass weight $(r=0.34$, $\mathrm{P}=0.001$ ).

Carcass yield has become very important to the production system in recent years, which was based on body weight and has to be done based on carcass weight. The carcass yield can be influenced by several aspects, including dietary fiber content (Ribeiro et al., 2001), animal category (Vaz et al., 2002), slaughter weight (Kuss et al, 2005) and genetic group (Menezes et al., 2005).
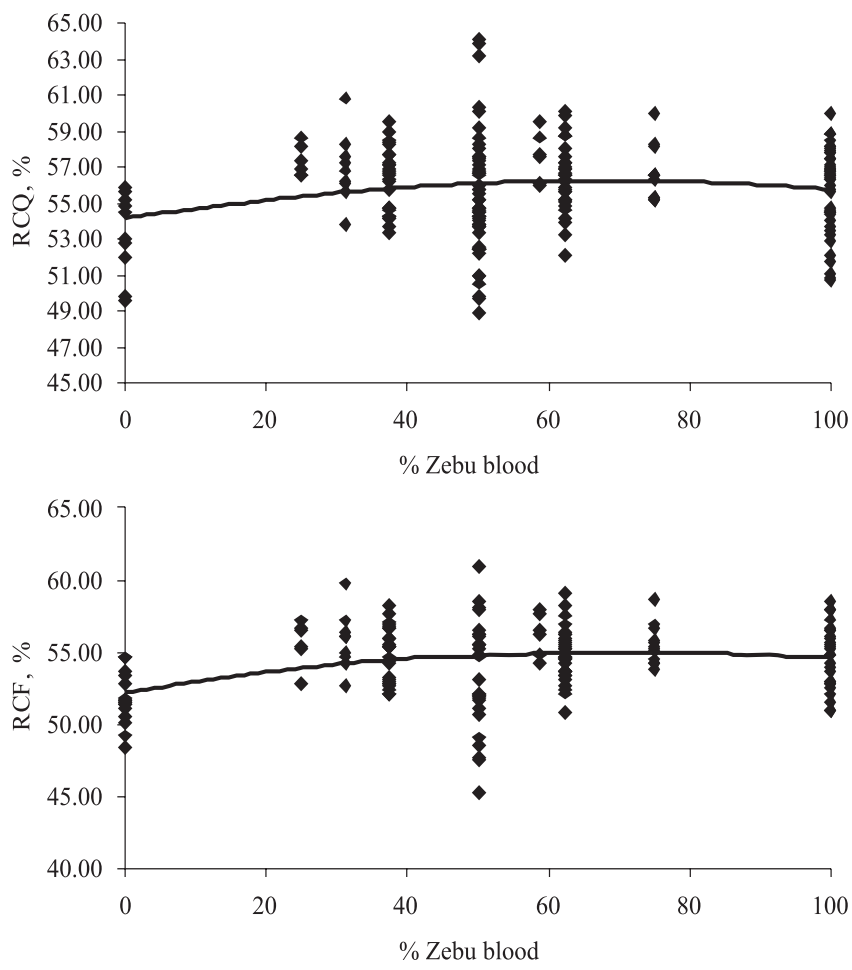

Figure 2 - Relationship between percentage of zebu blood and hot carcass yield (RCQ) and cold (RCF) of steers slaughtered at 24 months on average. [WC $=53.65+0.07026$ * Zebu - Zebu $0.00049 * 2\left(\mathrm{r}^{2}=0.45, \mathrm{P}=0.0002\right), \mathrm{RCF}=$ $51.91+0.078 *$ Zebu - Zebu $0.00048 * 2\left(r^{2}=0.516\right.$, $\mathrm{P}=0.0009)]$ 
The basic cuts of carcasses of cattle are: forequarter, sidecut and sawcut. Economically, a higher yield of the sawcut, compared with other cuts would be desirable, because of its higher market value. In all genetic groups, the percentage of sawcut was less than 50\% (Table 4).

On average, purebreds (European and zebu) had a lower percentage in relation to the sawcut of crossbreds, a fact confirmed by the regression equation, which was significant and quadratic (Figure 3). According to the regression equation $($ TRAS $=49.21994+0.04374 *$ zebu zebu $^{2 *} 0.0003706$ ), animals with $59 \%$ of zebu blood in the genotype had a higher percentage of sawcut (50.51\%) than purebreds. In the literature, there are no reports of heterosis effects on the percentage of sawcut (Faturi et al., 2002; Vaz et al., 2002; Menezes et al., 2005). The greater presence of sawcut in the carcass indicates more profit to the meat packing house, since, by multiplying the carcass weight by the percentage of the sawcut, there is increased production in $\mathrm{kg}$ of this cut in crossbred animals. The percentage for forequarter was positively influenced by increasing the degree of zebu blood in the genotype (Figure 3). This behavior can be attributed in part to the presence of hump in zebu animals (Luchiari Filho et al., 1985).

The sidecut percentage showed downward trend as it increased the share of zebu blood in the genotype. The sidecut percentage may be associated with the deposition of fat on this cut (Vaz et al., 2002), characteristic of animals that reach a high degree of finishing (Table 2) due to the bending of ribs, associated with selection for increasing food intake. Zebu breeds present less bending of ribs compared with European ones. Restle et al. (1999) also observed that the increase of the proportion of Nellore blood, replacing the

Table 4 - Statistics of position and dispersion for the percentage of primary cuts of the carcass according to the degree of blood in the genotype of zebu bulls

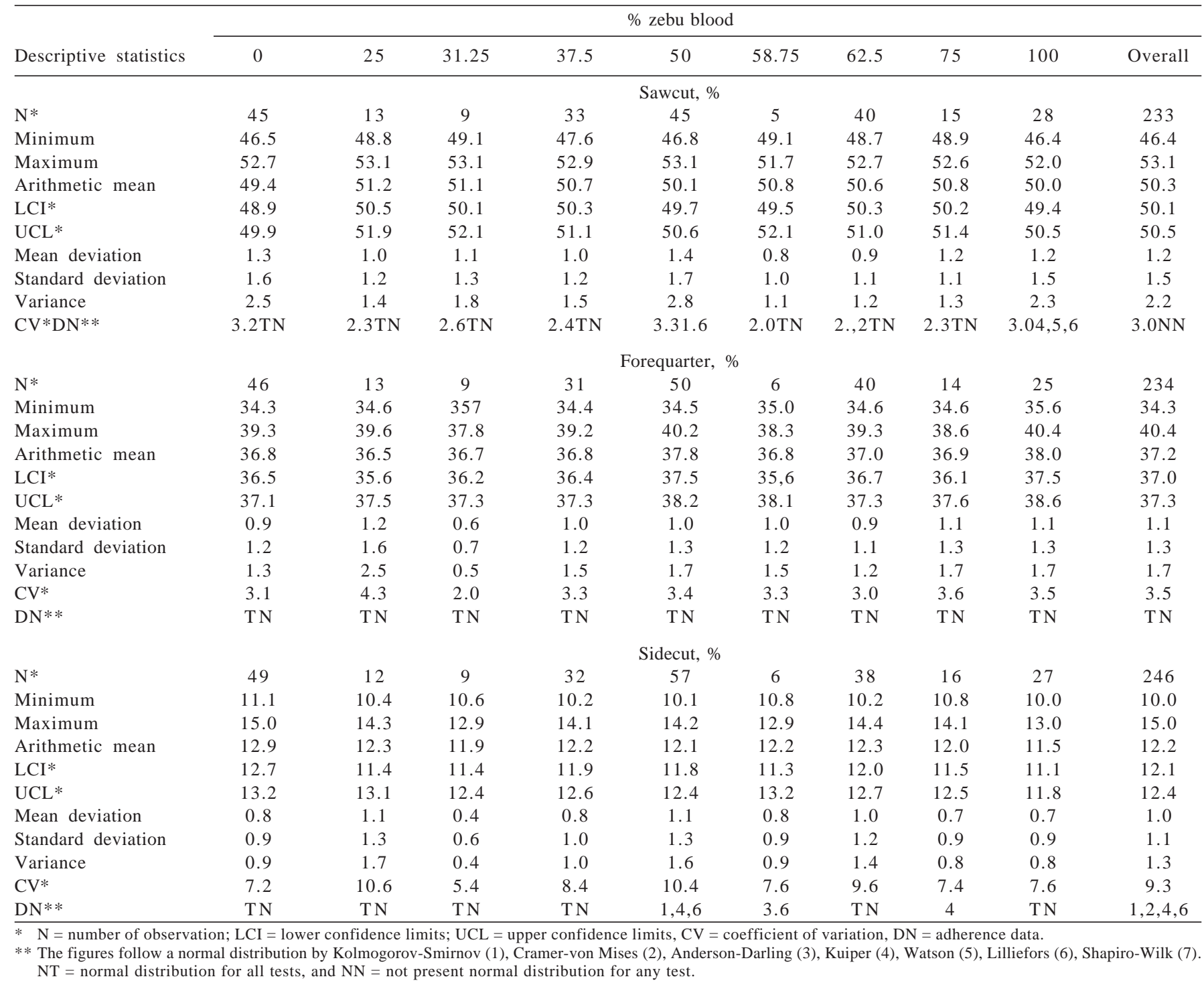



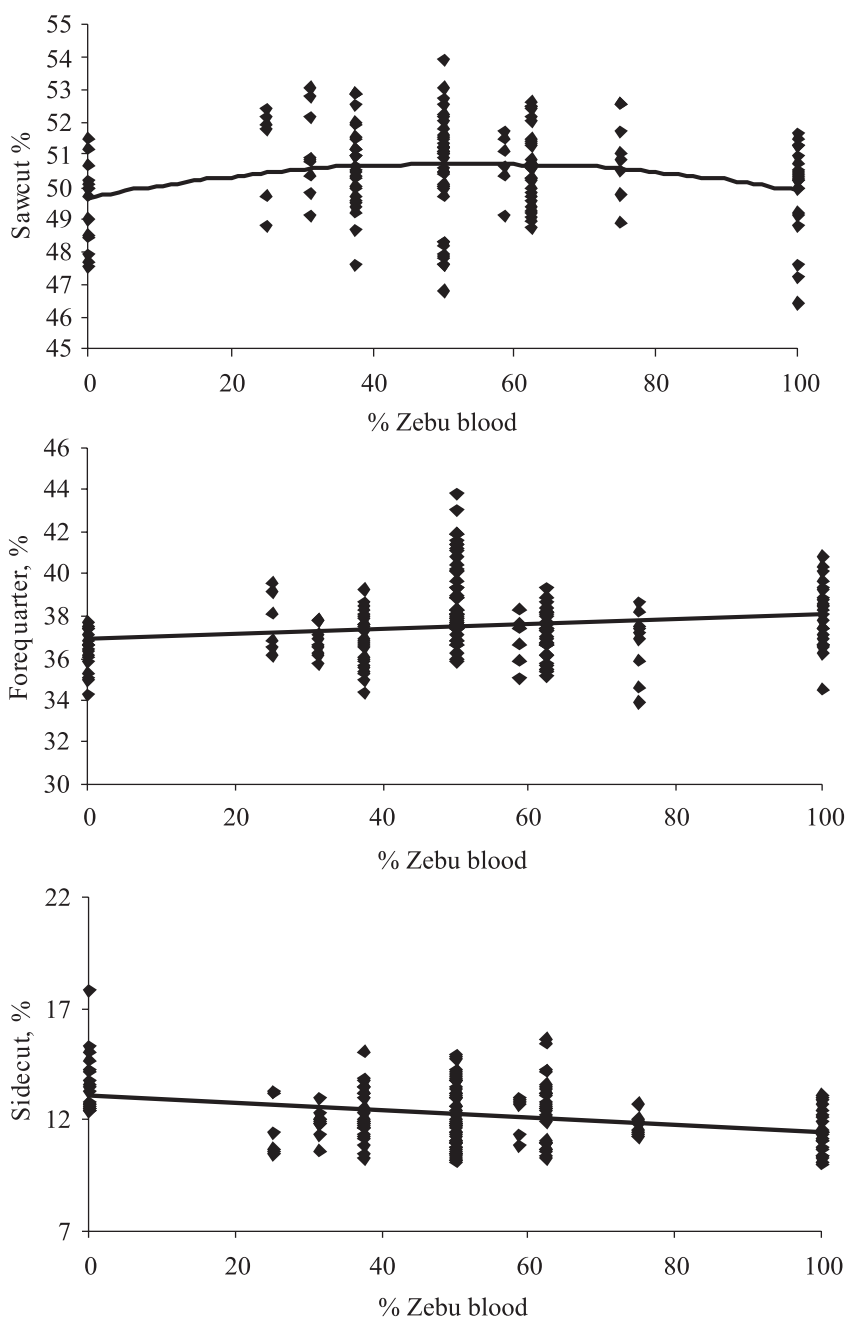

[Sawcut $=49.21994+0.04374 *$ Zebu - Zebu $0.0003706 * 2\left(\mathrm{r}^{2}=0.4333, \mathrm{P}=0.0003\right)$ Forequarter $=36.61898+0.01108 *$ zebu $\left(\mathrm{r}^{2}=0.25691 ; \mathrm{P}=0.0004\right)$; Sidecut $=$ 13.14567 to $0.0144 *$ zebu $\left.\left(\mathrm{r}^{2}=0.81509, \mathrm{P}=0.001\right)\right]$

Figure 3 - Relation between the percentage of zebu blood and the percentages of saw cut, forequarter and sidecut in the carcass of steers slaughtered at 24 months.

Hereford, decreased the sidecut percentage linearly. As in this analysis the thickness of subcutaneous fat was not influenced by the degree of blood, it is believed that the second hypothesis is more plausible.

\section{Conclusions}

The crossbreeding between European and zebu breeds results in carcasses of steers with greater weight, higher yield and higher percentage of saw cut, compared with purebreds. Zebu steers have higher percentage of forequarter and lower percentage of sidecut compared with steers of European breeds.

\section{Acknowledgements}

To CNPq, for granting the scholarship to Thomas Newton Martin and Douglas Vonz, and to MEC - SESU, for the scholarship to Tiago Venturini and Wagner Paris.

\section{References}

AFERRI, G. Desempenho e características da carcaça de novilhos alimentados com dietas contendo diferentes fontes de gordura. 2003. 43f. Qualidade e Produtividade Animal. Dissertação (Mestrado em Zootecnia) - Faculdade de Zootecnia e Engenharia de Alimentos/Universidade de São Paulo, Pirassununga.

ARBOITTE, M.Z.; RESTle, J.; ALVES FILHO, D.C. et al. Características da carcaça de novilhos 5/8 Nellore - 3/8 Charolais abatidos em diferentes estádios de desenvolvimento. Revista Brasileira de Zootecnia, v.33, n.4, p.969-977, 2004.

BONILHA, S.F.M.; PACKER, I.U.; FIGUEIREDO, L.A. et al. Efeitos da seleção para peso pós-desmame sobre características de carcaça e rendimento de cortes cárneos comerciais de bovinos. Revista Brasileira de Zootecnia, v.36, n.5, p.1275-1281, 2007.

CANESIN, R.C.; BERCHIELLI, T.T.; ANDRADE, P. et al. Características da carcaça e da carne de novilhos mantidos em pastagem de capim-marandu submetidos a diferentes estratégias de suplementação. Revista Brasileira de Zootecnia, v.35, n.6, p.2368-2375, 2006.

COAN, R.M.; REIS, R.A.; RESENDE, F.D. et al. Viabilidade econômica, desempenho e características de carcaça de garrotes em confinamento alimentados com dietas contendo silagem de capins Tanzânia ou Marandu ou silagem de milho. Revista Brasileira de Zootecnia, v.37, n.2, p.311-318, 2008.

COSTA, E.C.; RESTLE, J.; VAZ, F.N. et al. Características da carcaça de novilhos Red Angus superprecoces abatidos com diferentes pesos. Revista Brasileira de Zootecnia, v.31, n.1, p.119-128, 2002.

FATURI, C.; RESTLE, J.; BRONDANI, I.L. et al. Características da carcaça e da carne de novilhos de diferentes grupos genéticos alimentados em confinamento com diferentes proporções de grão de aveia e grão de sorgo no concentrado. Revista Brasileira de Zootecnia, v.31, n.5, p.2024-2035, 2002.

FEIJÓ, G.L.D.; EUCLIDES FILHO, K.; EUCLIDES, V.P.B. et al. Avaliação das carcaças de novilhos F1 Angus - Nellore em pastagens de Brachiaria decumbens submetidos a diferentes regimes alimentares. Revista Brasileira de Zootecnia, v.30, n.3, p.1015-1020, 2001 (supl. 1).

FREITAS, A.K.; RESTLE, J.; PACHECO P.S. et al. Características de carcaças de bovinos Nellores inteiros vs castrados em duas idades, terminados em confinamento. Revista Brasileira de Zootecnia, v.37, n.6, p.1055-1062, 2008.

HAUPTLI, L.; LOVATTO, P.A.; HAUSCHILD, L. Comparação da adição de extratos vegetais e antimicrobianos sintéticos para leitões na creche através de meta-análise. Ciência Rural, v.37, n.4, p.1084-1090, 2007.

IGARASI, M.S.; ARRIGONI, M.B.; HADLICH, J.C. et al Características de carcaça e parâmetros de qualidade de carne de bovinos jovens alimentados com grãos úmidos de milho ou sorgo. Revista Brasileira de Zootecnia, v.37, n.3, p.520-528, 2008.

KOGER, M.; PEACOCK, F.M.; KIRK, W.G. et al. Heterosis effects on weaning performance of Brahman-Shorton calves. Journal of Animal Science, v.40, n.5, p.826-833, 1975. 
KUSS, F. Características da carcaça e da carne e componentes não-integrantes da carcaça de vacas mestiças abatidas com pesos distintos. 2004. 140f. Dissertação (Mestrado em Zootecnia) - Universidade Federal de Santa Maria, Santa Maria.

KUSS, F.; RESTLE, J.; BRONDANI, I.L. et al. Composição física da carcaça e qualidade da carne de vacas de descarte de diferentes grupos genéticos terminadas em confinamento com distintos pesos. Revista Brasileira de Zootecnia, v.34, n.4, p.1285-1296, 2005.

LEME, P.R.; BOIN, C.; MARGARIDO, R.C.C. et al. Desempenho em confinamento e características de carcaça de bovinos machos de diferentes cruzamentos abatidos em três faixas de peso. Revista Brasileira de Zootecnia, v.29, n.6, p.2347-2353, 2000 (supl. 2).

LOPES, J.S.; RORATO, P.R.N; WEBER, T. et al. Metanálise para características de carcaça de bovinos de diferentes grupos genéticos. Ciência Rural, v.38, n.8, p.2278-2284, 2008.

LUCHIARI FILHO, A.; BOIN, C.; ALLEONI, G.F. et al. Efeito do tipo de animal no rendimento da porção comestível da carcaça. I. Machos da raça Nellore vs mestiços zebu x europeu terminados a pasto. Boletim da Indústria Animal, v.42, n.2, p.143-148, 1985.

MARCONDES, M.I.; VALADARES FILHO, S.C.; PAULINO, P.V.R. et al. Consumo e desempenho de animais alimentados individualmente ou em grupo e características de carcaça de animais Nellore de três classes sexuais. Revista Brasileira de Zootecnia, v.37, n.12, p.2243-2250, 2008.

MENEZES, L.F.G. Avaliação de novilhos das gerações avançadas do cruzamento rotativo Charolais - Nellore. 2004. 150f. Dissertação (Mestrado em Zootecnia) Universidade Federal de Santa Maria, Santa Maria.

MENEZES, L.F.G.; RESTLE, J.; BRONDANI, I.L. et al. Características da carcaça de novilhos de gerações avançadas do cruzamento alternado entre as raças Charolais e Nellore, terminados em confinamento. Revista Brasileira de Zootecnia, v.34, n.3, p.934-945, 2005.

MENEZES, L.F.G.; RESTLE, J.; BRONDANI, I.L. et al. Órgãos internos e trato gastrintestinal de novilhos de gerações avançadas do cruzamento rotativo entre as raças Charolais e Nellore terminados em confinamento. Revista Brasileira de Zootecnia, v.36, n.1, p.120-129, 2007.

MENEZES, L.F.G. Avaliação de diferentes sistemas de alimentação sobre as características que afetam a qualidade da carcaça e da carne. 2008. 167f. Tese (Doutorado em Zootecnia) - Universidade Federal de Santa Maria, Santa Maria.

MENEZES, L.F.G.; RESTLE, J.; BRONDANI, I.L. et al. Distribuição de gorduras internas e de descarte e componentes externos do corpo de novilhos de gerações avançadas do cruzamento rotativo entre as raças Charolais e Nellore. Revista Brasileira de Zootecnia, v.38, n.2, p.338-345, 2009.

METZ, P.A.M.; MENEZES, L.F.G.; ARBOITTE, M.Z. et al. Influência do peso ao início da terminação sobre as características de carcaça e da carne de novilhos mestiços Nellore x Charolais. Revista Brasileira de Zootecnia, v.38, n.2, p.346-353, 2009.

MULLER, L. Normas para avaliação de carcaças e concurso de carcaça de novilhos. 2.ed. Santa Maria: Universidade Federal de Santa Maria, 1987. 31p.

PACHECO, P.S. Desempenho, características da carcaça, da carne e do corpo vazio de novilhos jovens e superjovens de diferentes grupos genéticos. 2004. 236f. Dissertação (Mestrado em Zootecnia) - Universidade Federal de Santa Maria, Santa Maria, 2004.

PACHECO, P.S.; SILVA, J.H.S.; RESTLE, J. et al. Características quantitativas da carcaça de novilhos jovens e superjovens de diferentes grupos genéticos. Revista Brasileira de Zootecnia, v.34, n.5, p.1666-1677, 2005.
PEREIRA, A.S.C. Características qualitativas da carcaça e da carne das progênies de touros representativos da raça Nellore (Bos indicus) e de diferentes grupos genéticos. 2006. 114f. Tese (Doutorado em Zootecnia) - Faculdade de Zootecnia e Engenharia de Alimentos/Universidade de São Paulo, Pirassununga.

PINEDA, N.R.; ROCHA, J.C.M.C. [2002]. Perspectivas do mercado da carne bovina brasileira e estratégias preliminares de marketing. Available at: <http://www.beefpoint.com.br/?noticiaID =5260\&actA= 7\&areaID=15\&secaoID=12. Accessed on: Feb. 18, 2010.

PRADO, I.N.; PINHEIRO, A.D.; ALCALDE, C.R. et al. Níveis de substituição do milho pela polpa de Citrus peletizada sobre o desempenho e características de carcaça de bovinos mestiços confinados. Revista Brasileira de Zootecnia, v.29 n.6, p.2135-2141, 2000 (supl. 1).

RESTLE, J.; VAZ, F.N.; QUADROS, A.R.B. et al. Características de carcaça e da carne de novilhos de diferentes genótipos de Hereford x Nellore. Revista Brasileira de Zootecnia, v.28, n.6, p.1245-1251, 1999.

RESTLE, J.; QUADROS, A.R.B.; VAZ. F.N. Terminação em confinamento de novilhos de diferentes genótipos de Hereford x Nellore. Revista Brasileira de Zootecnia, v.29, n.1, p.125-130, 2000.

RESTLE, J.; VAZ, F.N.; ROSO, C. et al. Desempenho e características da carcaça de vacas de diferentes grupos genéticos em pastagem cultivada com suplementação energética. Revista Brasileira de Zootecnia, v.30, n.6, p.1813-1823, 2001.

RIBEIRO, E.L.A.; HERNANDEZ, J.A.; ZANELLA, E.L. et al. Desempenho e características de carcaça de bovinos de diferentes grupos genéticos. Revista Brasileira de Zootecnia, v.37, n.9, p.1669-1673, 2008.

RIBEIRO, T.R.; PEREIRA, J.C.; OLIVEIRA, M.V.M. et al. Características da carcaça de bezerros holandeses para produção de vitelos recebendo dietas com diferentes níveis de concentrado. Revista Brasileira de Zootecnia, v.30, n.6, p.2154-2162, 2001 (supl.).

SACHET, R.H. Reflexo do uso da silagem de milho na forma de suplemento para novilhos terminados em azevém. 2009. 89f. Dissertação (Mestrado em Zootecnia) - Universidade Federal de Santa Maria, Santa Maria.

SANTOS, A.P. Desempenho, características da carcaça e da carne de bovinos de diferentes sexos e idades, terminados em confinamento. 2005. 111f. Tese (Doutorado em Zootecnia) - Universidade Federal de Santa Maria, Santa Maria.

SANTOS, E.D.G.; PAULINO, M.F.; LANA, R.P. et al. Influência da suplementação com concentrados nas características de carcaça de bovinos F1 Limousin - Nellore, não-castrados, durante a seca, em pastagens de Brachiaria decumbens. Revista Brasileira de Zootecnia, v.31, n.4, p.1823-1832, 2002.

SILVA, F.A.S.; AZEVEDO, C.A.V. Versão do programa computacional Assistat para o sistema operacional Windows. Revista Brasileira de Produtos Agroindustriais, v.4, n.1, p.71-78, 2002.

SILVA, F.V.; ROCHA JÚNIOR, V.R.; BARROS, R.C. et al. Ganho de peso e características de carcaça de bovinos Nellore castrados ou não-castrados terminados em confinamento. Revista Brasileira de Zootecnia, v.37, n.12, p.2199-2205, 2008.

STATISTICAL ANALYSES SYSTEM - SAS. SAS/STAT: user's guide: statistics. 4.ed. Version 6, Cary: 2001. v.2.

SUNDSTROM, B.; BARLOW, R.; ARTHUR, P.F. Application of crossbreeding to beef production opportunities, obstacles and challenges. In: WORLD CONGRESS ON GENETICS APPLIED TO LIVESTOCK PRODUCTION, 5., 1994, Guelph. Proceedings... Guelph, 1994. n.l. p.148-167.

VAZ, F.N.; RESTLE, J. Características de carcaça e da carne de novilhos Hereford terminados em confinamento com diferentes fontes de volumoso. Revista Brasileira de Zootecnia, v.34, n.1, p.230-238, 2005. 
VAZ, F.N.; RESTLE, J. Ganho de peso antes e após os sete meses no desenvolvimento e nas características de carcaça e carne de novilhos Charolais abatidos aos dois anos. Revista Brasileira de Zootecnia, v.32, n.3, p.699-708, 2003.

VAZ, F.N.; RESTLE, J.; PACHECO, P.S. et al. Características de carcaça e da carne de novilhos superprecoces de três grupos genéticos, gerados por fêmeas de dois anos. Revista Brasileira de Zootecnia, v.31, n.5, p.1973-1982, 2002.

ZERVOUDAKIS, J.T.; PAULINO, M.F.; DETMANN, E. et al. Desempenho e características de carcaça de novilhos suplementados no período das águas. Revista Brasileira de Zootecnia, v.30, n.4, p.1381-1389, 2001. 